\title{
The Anti-Mercenary Norm and United Nations' Use of Private Military and Security Companies: From Norm Entrepreneurship to Organized Hypocrisy
}

\section{Oldrich Bures \& Eugenio Cusumano}

To cite this article: Oldrich Bures \& Eugenio Cusumano (2021) The Anti-Mercenary Norm and United Nations' Use of Private Military and Security Companies: From Norm Entrepreneurship to Organized Hypocrisy, International Peacekeeping, 28:4, 579-605, DOI: 10.1080/13533312.2020.1869542

To link to this article: https://doi.org/10.1080/13533312.2020.1869542

曲 Published online: 11 Jan 2021.

Submit your article to this journal $₫$

Џll Article views: 280

à

View related articles $\sqsubset$

View Crossmark data $₫$

Citing articles: 1 View citing articles $[7$ 


\title{
The Anti-Mercenary Norm and United Nations' Use of Private Military and Security Companies: From Norm Entrepreneurship to Organized Hypocrisy
}

\author{
Oldrich Bures (1) ${ }^{\mathrm{a}}$ and Eugenio Cusumano (10 ${ }^{\mathrm{b}, \mathrm{c}}$
}

${ }^{a}$ Center for Security Studies, Metropolitan University Prague, Prague 10, Czech Republic;

bInstitute for History, Faculty of Humanities, University of Leiden, Leiden, Netherlands;

'Department of Political and Social Sciences, European University Institute, Florence, Italy

\begin{abstract}
A prominent anti-mercenary norm entrepreneur in the second half of the twentieth century, the United Nations (UN) has become an equally prominent user of Private Military and Security Companies (PMSCs) services in the twenty-first century. In this article, we explain the gap between UN talk and action on private providers of security as a form of organized hypocrisy. To map the mismatch between UN rhetoric and behaviour in a measurable fashion, we combined official data on the use of PMSCs with an in-depth content analysis of the reports written by the UN Working Group on Mercenaries and an examination of the UN Department of Safety and Security (UNDSS) contracting policy. The Working Group's very negative portrayal of PMSCs and the UNDSS caveat that armed contractors should only be used as a last resort and stands in stark contrast with UN agencies' widespread use of private security providers. Although a decoupling between talk and action is often inevitable for complex organizations simultaneously pursuing contradictory objectives like the UN, our findings have important implications for peacekeeping. Most notably, organized hypocrisy is in danger of challenging the UN's credibility as a norm entrepreneur, hindering the effectiveness of its agencies' outsourcing practices and delaying the reform of UN peacekeeping and crisis management at large.
\end{abstract}

KEYWORDS United Nations; anti-mercenary norm; organized hypocrisy private military and security companies; peacekeeping

\section{Introduction}

In an influential article published in the European Journal of International Relations, Michael Lipson examined the large gap between United Nations (UN) talk and action on peacekeeping, conceptualizing the organization's failure to uphold the norms it rhetorically espouses as a form of organized hypocrisy. ${ }^{1}$ Since then, the concept of organized hypocrisy has been sparsely 
used to study peace and stability missions, ${ }^{2}$ the World Bank, ${ }^{3}$ and the European Union policies and agencies. ${ }^{4}$ However, the scholarship on the privatization of security has not yet employed the concept despite its utility in capturing the tension between established norms like the mercenary taboo, institutional constraints over the deployment of troops abroad, and the need for effective peace and crisis management operations.

In this article, we introduce the concept of organized hypocrisy in the study of private security by focusing on the UN's use of services provided by private military and security companies (PMSCs). Specifically, we utilize organized hypocrisy to make sense of the UN's transition from a prominent anti-mercenary norm entrepreneur in the second half of the twentieth century to an equally prominent user of PMSCs' services in the twentyfirst century. Since the end of the Cold War, the UN has simultaneously been expected to uphold the anti-mercenary norm and faced a growing inability to mobilize the manpower and expertise needed for effective crisis management. We argue that this tension has prompted a decoupling between UN talk and action on PMSCs. In the first decade of the twenty-first century, some UN bodies persisted in vocally condemning private security providers, while others progressively increased their use of PMSCs. In May 2011, the UN Secretary-General officially acknowledged the use of armed private security guards as a last resort for the first time, justifying contractor support as the outcome of the increasing demand for UN action in highly insecure (post)conflict areas and the continuing lack of supply of protection for UN personnel by host countries or other UN Member States. ${ }^{5}$ Shortly thereafter, the UN Department of Safety and Security (UNDSS) published specific guidelines on the use of PMSCs. ${ }^{6}$ These acknowledgements narrowed but did not completely bridge the gap between UN talk and action on security privatization. UN agencies' growing resort to PMSCs continues to stand in stark contrast with both the official UN policy formulated by the UNDSS, which restricts the outsourcing of security to exceptional circumstances, and the discourses by the UN Working Group on the Use of Mercenaries as a Means of Violating Human Rights and Impeding the Exercise of the Right of Peoples to Self-determination (from now on simply the Working Group), which replaced the pre-existing UN Special

\footnotetext{
'Lipson, "Peacekeeping: Organized Hypocrisy." For a critique, see Von Billerbeck, "No Action without Talk."

2Egnell, "The Organised Hypocrisy of International State-Building"; Hirschmann, "Peacebuilding in UN Peacekeeping Exit Strategies"; Everett, Humanitarian Hypocrisy.

${ }^{3}$ Weaver, Hypocrisy Trap: The World Bank and the Poverty of Reform.

${ }^{4}$ Cusumano, "Migrant Rescue as Organized Hypocrisy"; Knill, Steinebach, and Fernández-i-Marín, "Hypocrisy as a Crisis Response?"; Lavenex, "Failing Forward' Towards Which Europe?"

${ }^{5}$ UN Secretary General, "Use of Private Security," para. 8.

${ }^{6}$ UN Department of Safety and Security, "Guidelines on the Use of Armed Security Services from Private Security Companies."
} 
Rapporteur on Mercenaries. Unlike its predecessor, the Working Group begrudgingly acknowledged the difference between PMSCs and mercenaries but has continued to portray PMSCs in a very negative light, presenting them as problematic entities frequently responsible for human rights violations and expressing several principled objections against their use. Therefore, we argue that UN talk, decision-making, and action on PMSCs have remained decoupled, displaying a considerable degree of hypocrisy.

It is important to note that the UN has always stressed that it only uses defensive security services of private security companies (PSCs) and not military services of private military companies (PMCs). ${ }^{7}$ While this is empirically correct in cases where the UN directly hires security services (see below), the line between military and security services is often blurred. Moreover, the same companies contracted by the UN are also known to provide military services to other clients in the same areas of operation. Thus, in line with the current academic literature and the 2008 Montreux Document, ${ }^{8}$ which summarizes the pertinent international legal obligations and good practices for states' use of private security services, we use the umbrella term 'private military and security companies' and the corresponding abbreviation PMSCs.

To map the mismatch between talk and action in a measurable fashion, we combine official UN data on the use of PMSCs and a content analysis of UN documents discussing the privatization of security and its implications. As 'a technique for making inferences by systematically and objectively identifying characteristics of specified messages', ${ }^{9}$ content analysis provides an ideal tool for examining organizations' rhetoric and the extent to which it is decoupled from behaviour. We mainly (but not exclusively) focus on an in-depth examination of the Working Group's talk for two reasons. First, the Working Group is the only UN body officially tasked with monitoring, regulating and sanctioning mercenaries and mercenary-related activities as well as (formally since September 2014) PMSCs. This narrow mandate has enabled the Working Group to produce a large body of documents on security privatization. Second, and relatedly, the rest of the UN system rarely mentioned PMSCs and their use in their official talk. As the UN is a complex organization with multiple identities and multiple centres of agency, its talk often resembles a polyphony or even a cacophony of different voices. ${ }^{10}$ However, this general tendency does not neatly apply to security privatization, an issue on which most UN bodies and agencies have remained nearly entirely silent. As the Working Group is the only UN body engaged

\footnotetext{
${ }^{7} \emptyset$ stensen, "UN Use of Private Military and Security Companies," 7.

${ }^{8}$ International Committee of the Red Cross, "The Montreux Document on Private Military and Security Companies."

${ }^{9}$ Holsti, Content Analysis for the Social Sciences and Humanities, 25.

${ }^{10}$ Von Billerbeck, "No Action without Talk"; Karlsrud, "Multiple Actors and Centres of Agency?"
} 
in an extensive, longstanding discussion of security privatization, only its talk can be systematically examined through content analysis. However, we have also complemented the Working Group discussions' content analysis with an examination of the occasional mentions to PMSCs made by the General Assembly, the Secretary General, and, most notably, the Department of Safety and Security.

By collecting all the reports drafted by the Working Group since 2008, we built a corpus of over 418,000 words, examined through the data analysis software MAXQDA. We then quantitatively counted the frequency of keywords revealing a negative assessment of PMSCs and qualitatively assessed the content and intensity of this criticism. By examining each of these keywords within its context, we excluded all negative references to actors other than PMSCs sometimes discussed by the Working Group, such as traditional mercenaries and foreign fighters. We then investigate UN action by using existing official figures on UN spending on PMSCs gathered from the Annual Statistical Reports on UN Procurement and the data provided by the UN Procurement Division. As no systematic data on UN use of PMSCs before 2008 is available, we focus our analysis on the period between 2008 and 2019.

While the peculiarity of the Working Group's mandate, other UN agencies' silence on PMSCs, and the subsequent difficulties attached to estimate their use entails some limitations and warrant additional studies, our research design provides a twofold contribution to the existing literature. First, we innovate on existing private security studies by showing the heuristic utility of organized hypocrisy in capturing the tension between the normative commitment to a state monopoly of violence and the growing material and political incentives attached to the use of PMSCs. Second, we contribute to ongoing debates on international norms change by highlighting a phenomenon that existing norms scholarship has not yet thoroughly examined: the fact that existing norms are often rhetorically adhered to, but at least partly violated in practice.

This article is structured as follows. The next section briefly reviews the notion of organized hypocrisy, applying it to the UN system and the privatization of security services therein. Section three introduces the antimercenary norm and the role played by the UN in its institutionalization. Section four focuses on UN action, examining the increasing use of PMSCs in UN operations. Section five focuses on UN talk, illustrating the persistence of strong criticism against commercial providers of security through a content analysis of UN Working Group reports. Section six analyses the article's findings, explaining the decoupling between the Working Group discourse and UNDSS policy on PMSCs and UN agencies' growing use of contractors. The concluding section fleshes out 
the implications of our findings and sketches some avenues for future research.

\section{Organized Hypocrisy}

Institutionalist scholars have long acknowledged that organizations' structures and behaviour are shaped by both material constraints and societal expectations of conformity with existing normative standards. ${ }^{11}$ All organizations owe their survival to their external environment, from which they draw authority, legitimacy, and resources. As they are informed by different norms and interests, however, the demands imposed on organizations by their external constituencies are far from consistent. ${ }^{12}$ All collective actors face conflicting normative logics of appropriateness and instrumental logics of consequences. ${ }^{13}$ Consequently, they tend to develop separate, 'decoupled' responses to these contradictory pressures. ${ }^{14}$

As collective actors reflect their external environment in their internal structure, organizations facing contradictory external pressures are likely to decouple their internal processes. To comply with existing societal expectations, appropriate formal structures are then created within an organization. However, such structures are also decoupled - that is, causally disconnected - from incompatible internal activities. Accordingly, for instance, organizations could develop affirmative action offices without revising their hiring practices, or draft codes of conduct outlining their corporate social responsibility while keeping their labour and environmental standards unchanged. This tendency to decouple internal structure and processes is referred to as the organization of hypocrisy. ${ }^{15}$ By incorporating the contradictions inherent in its member states' different normative expectations into its diverse sets of bodies and agencies, the UN system is a clear example of the organization of hypocrisy. ${ }^{16}$

Besides stovepiping their internal functioning, organizations facing contradictory demands also tend to decouple their external outputs. When asked to satisfy demands that are in contradiction with one another or incompatible with existing constraints and available resources, organizations are likely to decouple talk, decisions, and action, rhetorically embracing publicly accepted norms even though these norms are inconsistent with their behaviour. Consequently, what organizations 'say' frequently diverges

\footnotetext{
${ }^{11}$ DiMaggio and Powell, "The Iron Cage Revisited"; March and Olsen, Rediscovering Institutions; Meyer and Rowan, "Institutionalized Organizations."

${ }^{12}$ Brunsson, The Organization of Hypocrisy: Talk, Decisions, and Actions in Organizations; Weaver, Hypocrisy Trap.

${ }^{13}$ March and Olsen, Rediscovering Institutions.

${ }^{14}$ Brunsson, The Organization of Hypocrisy.

${ }^{15}$ Brunsson, The Organization of Hypocrisy.

${ }^{16}$ Lipson, "Peacekeeping," 12.
} 
from what they actually 'do'. This mismatch between the words and deeds of organizations was first conceptualized by organization theorist Nils Brunsson as organized hypocrisy. ${ }^{17}$ When organizations face contradictory pressures, norms may be rhetorically reiterated precisely to compensate for the lack of consistent action, thereby addressing external demands to tackle an issue without really acting upon it. ${ }^{18}$

As they have 'multiple masters' with different demands and expectations ${ }^{19}$ and consist of large, complex bureaucracies where decisions are announced, made, and implemented by different departments and individuals, international organizations are especially prone to hypocrisy. Organized hypocrisy, however, was introduced in the field of international relations by Stephen Krasner to examine the institution of sovereignty, often rhetorically affirmed but, in fact, systematically violated by the rulers of powerful states in the international system. ${ }^{20}$ Although we resonate with Krasner in arguing that states' commitment to a monopoly of violence is often a form of organized hypocrisy like sovereignty itself, our work draws primarily on the work of Brunsson, ${ }^{21}$ Barnett and Coleman ${ }^{22}$ - who first examined international organizations' tendency to project an appearance of norm conformity while continuing business as usual - and Lipson ${ }^{23}$ - who first applied the notion of hypocrisy to the gap between talk and action in UN peacekeeping.

As it is simultaneously involved in peacekeeping and international development as well as the dissemination of international norms and principles, the UN has both a normative and an operational identity. ${ }^{24}$ As noted by Lipson, the UN's legitimacy rests upon its ability to exemplify and uphold widely held international norms. Such norms, however, cannot be simultaneously adhered to when conducting peace operations. For instance, upholding a responsibility to protect through crisis management operations is hardly compatible with the non-interference in states' domestic affairs underlying the principle of sovereignty. Moreover, normative imperatives like preventing genocide clash with both institutional and material constraints, such as the frequent deadlocks within the UN Security Council and member states' unwillingness to provide the resources required to conduct effective peacekeeping missions. Hypocrisy especially pervades the reform of UN peacekeeping, ${ }^{25}$ the development of exit strategies from

\footnotetext{
${ }^{17}$ Brunsson, The Organization of Hypocrisy; Brunsson, The Consequences of Decision-Making.

${ }^{18}$ Brunsson, The Consequences of Decision-Making, 116; Lipson, "Peacekeeping."

${ }^{19}$ Weaver, Hypocrisy Trap, 4-5.

${ }^{20}$ Krasner, Sovereignty: Organized Hypocrisy.

${ }^{21}$ Brunsson, The Organization of Hypocrisy; Brunsson, The Consequences of Decision-Making.

${ }^{22}$ Barnett and Coleman, "Designing Police."

${ }^{23}$ Lipson, "Peacekeeping."

${ }^{24}$ Von Billerbeck, "Mirror Mirror on the Wall," 210.

${ }^{25}$ Lipson, "Peacekeeping."
} 
peacekeeping missions, ${ }^{26}$ as well as the mandates of civilian protection ${ }^{27}$ and state-building operations. ${ }^{28}$

Since Lipson's article, ensuing IR scholarship has made scant reference to the notion of organized hypocrisy and primarily employed the concept to examine other international organizations, such as the World Bank, ${ }^{29}$ and different agencies within the European Union. ${ }^{30}$ While continuing to highlight the existence of multiple, conflicting patterns of talk and action and the dysfunctions attached thereto, ${ }^{31}$ recent UN peacekeeping studies mainly focus on related but distinct issues, such as the use of discourse for institutional self-legitimation ${ }^{32}$ or competing advocacy coalitions' efforts to promote norm change within the organization. ${ }^{33}$

In the remainder of this article, we refocus the concept of organized hypocrisy on the UN to shed light on the persisting gap between talk and action regarding PMSCs. Private military and security contractors continue to be referred to as a last resort by UN official policy and flagged as intrinsically problematic actors by the Working Group, Nevertheless, they are increasingly relied on by all parts of the UN system, including its humanitarian, political, and peacekeeping missions.

\section{The Anti-Mercenary Norm and the Role of the United Nations in Its Institutionalization}

The post-Cold War proliferation of PMSCs has raised numerous questions about the scope and relevance of the international norm against mercenaries, whose origins can be traced as far back as the Middle Ages. Sarah Percy, who first conceptualized the prohibition to use mercenaries as a norm in a booklength analysis, contended that there is 'a clear thread of continuity between the pre-nineteenth century variants of the anti-mercenary norm and those of the twentieth and twenty-first centuries', identifying two key aspects: (1) the belief that mercenaries are negative actors because they do not fight for a proper cause, and; (2) the belief that mercenaries are uncontrolled, thereby undermining the role of the state as the primary holder of the monopoly of the use of force. ${ }^{34}$ Since the norm's prescriptive scope hinges on a definition of a mercenary, this approach offers a plausible way out of a hitherto inconclusive debate on whether PMSCs are legitimate security

\footnotetext{
${ }^{26}$ Hirschmann, "Peacebuilding in UN Peacekeeping Exit Strategies."

${ }^{27}$ Everett, Humanitarian Hypocrisy.

${ }^{28}$ Egnell, "The Organised Hypocrisy of International State-Building."

${ }^{29}$ Weaver, Hypocrisy Trap.

${ }^{30}$ Cusumano, "Migrant Rescue as Organized Hypocrisy"; Knill, Steinebach, and Fernández-i-Marín, "Hypocrisy as a Crisis Response?"; Lavenex, "Failing Forward' Towards Which Europe?."

${ }^{31}$ Junk and Trettin, "Internal Dynamics and Dysfunctions of International Organizations."

${ }^{32}$ Von Billerbeck, "Mirror Mirror on the Wall"; Von Billerbeck, "No Action without Talk."

${ }^{33}$ Karlsrud, "Multiple Actors and Centres of Agency?"

${ }^{34}$ Percy, Mercenaries: The History of a Norm in International Relations, 218-9.
} 
providers or little more than corporatized mercenaries deserving moral and legal opprobrium. According to Percy, twenty-first-century PMSCs should not be considered mercenaries because they share a commitment to a greater cause when they fight for their home state's goals, contract 'primarily' with their home state, or work only on projects formally or informally approved by their home state. ${ }^{35}$ As she acknowledges, however, PMSCs 'do not entirely avoid the anti-mercenary norm', which still shapes both the opportunities available to PMSCs and the ways states and other actors use them. ${ }^{36}$

There are several alternative accounts of the history, ${ }^{37}$ evolution, ${ }^{38}$ and strength $^{39}$ of the anti-mercenary norm. Some of these accounts suggest that since the mid-2000s, states keen to use PMSCs (in particular the US and the UK) and PMSCs' representatives exploited the definitional vagueness of norm to restrict its regulatory scope by promoting a differentiation between an offensive use of military force in combat and the provision of defensive security services. ${ }^{40}$ Nevertheless, even this follow-up scholarship has forcefully emphasized that if Percy's two-part definition of mercenaries 'is taken for granted, PMSCs come under the regulatory scope of the norm', because they too are motivated by profit, thereby lacking an appropriate cause for engaging in hostility, and are insufficiently controlled and regulated by states. ${ }^{41}$ As we show in this article, these two key normative claims can also be found in the majority of the reports by the UN Working Group, which are deeply permeated by a lingering sense that private force is morally problematic. ${ }^{42}$ This wariness is not only directed at armed private security providers in (post-)conflict zones, but it also relates to the provision of unarmed services like intelligence, detention services, and migration management. Most notably, Working Group reports frequently stress that the profit-driven nature of PMSCs is fundamentally incompatible with peace, security, as well as social justice, and that their activities lack transparency, regulation, and accountability. Consequently, for the purpose of this article, any extensive use of PMSCs can be considered as a violation of the Working Group's orthodox interpretation of the norm.

\footnotetext{
${ }^{35}$ Ibid., 235.

${ }^{36}$ Ibid., 232; Percy, "The Unimplemented Norm," 80.

${ }^{37}$ Thomson, Mercenaries, Pirates, and Sovereigns.

${ }^{38}$ Fitzsimmons, "A Rational-Constructivist Explanation for the Evolution and Decline of the Norm against Mercenarism"; Krahmann, "The United States, PMSCs and the State Monopoly on Violence"; Panke and Petersohn, "Why International Norms Disappear Sometimes"; Panke and Petersohn, "Norm Challenges and Norm Death."

${ }^{39}$ Bures and Meyer, "The Anti-Mercenary Norm and United Nations' Use of Private Military and Security Companies"; Casiraghi, "Weak, Politicized, Absent"; Liu and Kinsey, "Challenging the Strength of the Antimercenary Norm"; White, "Mercenarism, Norms and Market Exchange."

${ }^{40}$ Petersohn, "Reframing the Anti-Mercenary Norm."

${ }^{41}$ Ibid., 480-1.

${ }^{42}$ Percy, "The Unimplemented Norm," 240.
} 
Working Group reports also resonate with studies claiming that the persisting stigma attached to commercial providers of violence is due to the inter-linkage of different norms. According to Krahmann, for example, 'the differentiation between mercenaries who fight in "combat" and PMSCs who engage in "defensive operations", along with the 'discursive reinterpretation of the core functions of the state and the military' occurred the mid-2000s, reveals a transformation in the norm prescribing a state monopoly on violence, 'while at the same time the norm against mercenarism has remained strong. ${ }^{43}$ Alternatively, Liu and Kinsey suggested that the antimercenary norm 'is not as strong as its supporters suggest', and maintained that the 'international restrictions placed upon mercenaries are the tangential expressions of more basic and pervasive international norms, namely state neutrality, the right of peoples to self-determination, and freedom of movement ${ }^{34}$ While arguing that the prohibition to use mercenaries had a 'puritanical' impact in the 1990s and early 2000s, Percy too acknowledged that its compliance pull was not only a consequence of its long history and early institutionalization, but also of its linkage to other powerful norms, including citizens' military duty to the state, self-determination, and decolonization. ${ }^{45}$

Although it remains an open question how salient any of the aforementioned norms will be in the future, they would all have to be significantly eroded for the anti-mercenary prohibition itself to lose all its strength. To a large extent, this is a consequence of the UN's crucial role in the diffusion, institutionalization, and interlinking of many of these norms. In particular, promoting national self-determination and decolonization was a key part of the UN's agenda during the Cold War. In the early 1990s, these norms also offered a new opportunity to attack PMSCs: the argument that 'that mercenaries in any form challenged national self-determination ... even though there was little empirical evidence that self-determination was undermined by the 1990s variant of private force'. ${ }^{46}$

Since the 1960s, the UN General Assembly has passed more than 100 resolutions criticizing mercenaries. In 1968, for example, Resolution 2465 explicitly referred to mercenaries as 'outlaws' and called for all states 'to enact legislation declaring the recruitment, financing, and training of mercenaries in their territory to be a punishable offence and prohibiting their nationals from serving as mercenaries'. ${ }^{47}$ Mercenaries were also explicitly flagged in the 1974 UN General Assembly's Definition of Aggression ${ }^{48}$ and the

\footnotetext{
${ }^{43}$ Krahmann, "The United States, PMSCs and the State Monopoly on Violence," 65.

${ }^{44} \mathrm{Liu}$ and Kinsey, "Challenging the Strength of the Antimercenary Norm," 93.

${ }^{45}$ Percy, Mercenaries, 35.

${ }^{46}$ Ibid., 29.

${ }^{47}$ UN General Assembly, "Implementation of the Declaration on the Granting of Independence to Colonial Countries and Peoples."
} 
resolution on the importance of the universal realization of the right of peoples to self-determination', issued in 1979 and reaffirmed annually until 2005, according to which the use of 'mercenaries against national liberation movements and sovereign States constitutes a criminal act and ... mercenaries themselves are criminals' ${ }^{49}$ In the 1960s and 1970s, the UN Security Council also adopted several resolutions condemning states that permitted the recruitment of mercenaries. ${ }^{50}$ Similar statements can be found in numerous reports of the former UN Special Rapporteur on mercenaries, who also considered PMSCs a 'new operational model of mercenarism' that threatened the civilian populations, peace, and state's sovereignty. ${ }^{51}$ From 1987 until 2005, when the post was replaced with the Working Group, the Rapporteur's reports reflected the moral disapproval of both mercenaries and PMSCs by the UN High Commission for Human Rights (since 2006 the Human Rights Council), the body within the United responsible for strengthening the promotion and protection of human rights around the globe.

Jointly, these numerous UN resolutions and reports set the stage for further legal institutionalization of the anti-mercenary norm, manifested in the 1989 UN International Convention against the Recruitment, Use, Financing and Training of Mercenaries. Even though the Convention has been ratified by only 36 states thus far, it still represents the sole binding international legal instrument covering mercenaries. These documents also influenced the thinking of senior UN officials in the Secretariat and key UN agencies, which only rarely outsourced support services in the 1990s and early 2000s, albeit the possibility of using private force have been mooted on several occasions within the UN system. ${ }^{52}$ Therefore, one can concur with Percy that 'the UN has acted as a sort of world-class publicist in reverse for mercenaries. ${ }^{53}$

\section{Action: UN Use of Private Military and Security Companies}

As discussed in the previous section, during the second half of the twentieth century the UN Security Council, General Assembly and Special Rapporteur promoted an orthodox version of the anti-mercenary norm, which prohibited the use of private force. Accordingly, the UN could not even seriously

\footnotetext{
${ }^{48}$ UN General Assembly, Definition of Aggression.

${ }^{49}$ UN General Assembly, "Importance of the universal realization of the right of peoples to self-determination and of the speedy granting of independence to colonial countries and peoples for the effective guarantee and observance of human rights."

${ }^{50}$ UN Security Council, "UN Security Council Resolution 241 (1967)"; UN Security Council, "UN Security Council Resolution 405 (1977)."

${ }^{51}$ Ballesteros, "Report on the Question of the Use of Mercenaries as a Means of Violating Human Rights and Impeding the Exercise of the Rights of Peoples to Self-Determination," para. 68.

${ }^{52}$ Percy, Mercenaries, 222; Bures, "Private Military Companies?"

${ }^{53}$ Percy, Mercenaries, 239.
} 
contemplate an extensive use of either mercenaries or PMSCs. Although some agencies used specialized transportation and logistical services already in the $1990 \mathrm{~s},{ }^{54}$ widespread security outsourcing of security and military support tasks within the UN system only started in the early-2000s. Since then, however, contracting the services of PMSCs has become a common and systematic practice in most, if not all, UN agencies, funds, programmes, departments, country teams, and local duty stations. UN agencies have used PMSCs for a wide range of activities, including both armed and unarmed security, risk assessment, security training and management, logistical support, base construction, transportation, convoy protection, consultancy, and other specialized services such as demining, election support, intelligence, and security sector reform. The use of PMSCs has also been documented in all types of UN field missions, including humanitarian, political, as well as peacekeeping missions. ${ }^{55}$

When it comes to UN reports, however, specific data on the use of PMSCs has been published only twice thus far. In December 2012, the annexes of a report by the Advisory Committee on Administrative and Budgetary Questions first offered concrete information regarding the numbers of armed PMSCs personnel used in UN political missions and peacekeeping operations in the 2012-2013 period. Specifically, the report indicated that as of October 42 PMSCs were under contract with UN missions and operations, employing over 5,000 armed private guards and costing $\$ 30,931,122 .^{56}$ The lists of both political and peacekeeping missions also revealed that while the UN primarily used armed PMSCs in conflict and post-conflict settings in Africa (15 countries) and in the Middle East ( 3 countries), private security was also procured for the UN Global Support Centre in Spain. The report included the name of the PMSCs used, the number of contracted personnel, and the budget requested and approved for all missions, but specified the services outsourced only for two missions - United Nations Assistance Mission for Iraq (UNAMI) and United Nations Assistance Mission in Afghanistan (UNAMA). In the case of UNAMI, Al-Soqoor Security Services and Protection Co. and Global Shield for Trade and Security provided security guards, and Ronco Consulting Corp. provided explosive detection devices. In the case of UNAMA, IDG Security Ltd. provided both armed and unarmed static guards and canine services. ${ }^{57}$

\footnotetext{
${ }^{54}$ Bures, "Private Military Companies"; Østensen, "UN Use of Private Military and Security Companies."

${ }^{55}$ Bures and Meyer, "The Anti-Mercenary Norm and United Nations' Use of Private Military and Security Companies"; Østensen, "UN Use of Private Military and Security Companies"; Østensen, "In the Business of Peace"; Patterson, "A Corporate Alternative to United Nations Ad Hoc Military Deployments"; Pingeot, "Dangerous Partnership - Private Military \& Security Companies and the UN"; Tkach and Phillips, "UN Organizational and Financial Incentives to Employ Private Military and Security Companies in Peacekeeping Operations."

${ }^{56}$ Advisory Committee on Administrative and Budgetary Questions, "Reports on the Department of Safety and Security and on the Use of Private Security."
} 
The second UN report with specific data on UN's PMSCs contracting is the August 2014 report by the UN Working Group. While not providing lists of PMSCs' contracts in different UN missions, the report stated that as of May 2014,30 companies had been used in peacekeeping missions and political missions. The report specifically listed only 12 peacekeeping missions and one facility of the Department of Field support, claiming that of the total of 4,412 security guards contracted by these 13 entities, only 574 were armed'. It also stated that from the total estimated budget for 2013/2014 for the use of PMSCs (approximately \$42,125,297), \$14,015,520 was allocated for 'armed services' in just two missions/countries, namely MINUSTAH/Haiti $(\$ 5,125,200)$ and UNAMA/Afghanistan $(\$ 8,890,320) .{ }^{58}$ The report also contains two case studies of UN's use of PMSCs in Afghanistan and Somalia. In Afghanistan's case, the report confirmed that IDG Security Limited provided both armed and unarmed Gurkha guards 'for internal duties in the UNAMA compound' ${ }^{59}$ Interestingly, it also noted that various UN agencies, funds and programmes had their own separate contracts for additional internal unarmed guards in their respective areas of the UNAMA compound. Specifically, the report stated that the United Nations Children's Fund had a contract with Triple Canopy, the US PMSC that absorbed most of the former US special operations forces previously working for the infamous PMSC Blackwater, while the Office of the United Nations High Commissioner for Refugees hired the British firm Hart Security. ${ }^{60}$ In the case of Somalia, the Working Group conducted a site visit in December 2012 and observed that the United Nations Development Programme (UNDP) contracted a local company that provided a wide range of security services, including armed security escorts and protection services, threat and risk assessments, communications, logistics, and dispatch services' ${ }^{61}$ The report also noted that 'several local security providers in Somalia were clan-based militias that operate behind a corporate facade in order to conceal the involvement of individual warlords' ${ }^{62}$

As pointed out by Bures and Meyer, the data presented in these UN reports is of questionably quality due to discrepancies within the reported figures and the apparent lack of understanding of the complex global nature of the PMSCs business by their authors (referred to as 'representatives of the Secretary-General'). ${ }^{63}$ For example, although the authors of the 2012

\footnotetext{
${ }^{57}$ Ibid., 11-12.

${ }^{58}$ UN Working Group on the Use of Mercenaries, "Use of Mercenaries as a Means of Violating Human Rights and Impeding the Exercise of the Right of Peoples to Self-Determination," para. 11.

${ }^{59}$ Ibid., para. 52.

${ }^{60}$ lbid., para. 52.

${ }^{61}$ Ibid., para. 60.

${ }^{62}$ Ibid., para. 61.

${ }^{63}$ Bures and Meyer, "The Anti-Mercenary Norm and United Nations' Use of Private Military and Security Companies."
} 
report informed the Committee that the UN system had 'only one contract with a large multinational armed private security company' (IDG Security in Afghanistan), ${ }^{64}$ they listed in the annexes several contracts for armed security with local branches of G4S - the largest private security provider worldwide - in Cameroon, Haiti, and Kosovo. Uncertainty related to UN use of PMSCs also has several technical explanations, including client confidentiality clauses in PMSCs contracts and poor record keeping and reporting across the UN system as a whole, as well as within the Secretariat and individual parts of the UN system. ${ }^{65}$

To complement the problematic data from UN reports, we searched the Annual Statistical Reports on UN Procurement and the statistics provided by the UN Procurement Division. Since 2009, the Annual Statistical Reports include data for two further unspecified categories of 'Security Services' and 'Security and Safety Equipment', which offer insights into security outsourcing by the entire UN system. Importantly, these figures cover most key UN funds, programmes, and agencies that procure their own contracts with PMSCs. In contrast, the statistics provided since 2007 by the UN Procurement Division include data for security procurement of UN Headquarters and local UN missions only. Albeit the data in the annual UN Statistical Reports and the UN Procurement Division databases may be incomplete and the specific figures that they provide often differ, ${ }^{66}$ it does allow for tracking the overall trends of UN expenditures on security procurement over the last decade. As indicated in Figure 1, there has been an overall 486\% increase in the UN's total expenditures on security services and security equipment contracting between 2009 and 2018. This spike is primarily due to the procurement of further unspecified security services, which substantially exceeded the purchases of security equipment in all years. Equally remarkable is the $455 \%$ increase in UN's total expenditures on security procurement by UN Headquarters and local missions between 2007 and 2019, captured in Figure 2.

\section{Talk: Working Group Discourse Regarding the Use of Private Military and Security Companies}

As demonstrated in the previous section, it would be difficult to find a part of the UN system that has not used PMSCs in the last decade. Peacekeeping operations have witnessed an especially pervasive use of contractors for the provision of security and logistical support. However, in contrast to numerous arguments in favour of the UN's use of PMSCs discussed by the

\footnotetext{
${ }^{64}$ Advisory Committee on Administrative and Budgetary Questions, "Reports on the Department of Safety and Security and on the Use of Private Security," para. 23.

${ }^{65} \emptyset$ stensen, "UN Use of Private Military and Security Companies," 8-9.

${ }^{66}$ Pingeot, "Dangerous Partnership," 47.
} 


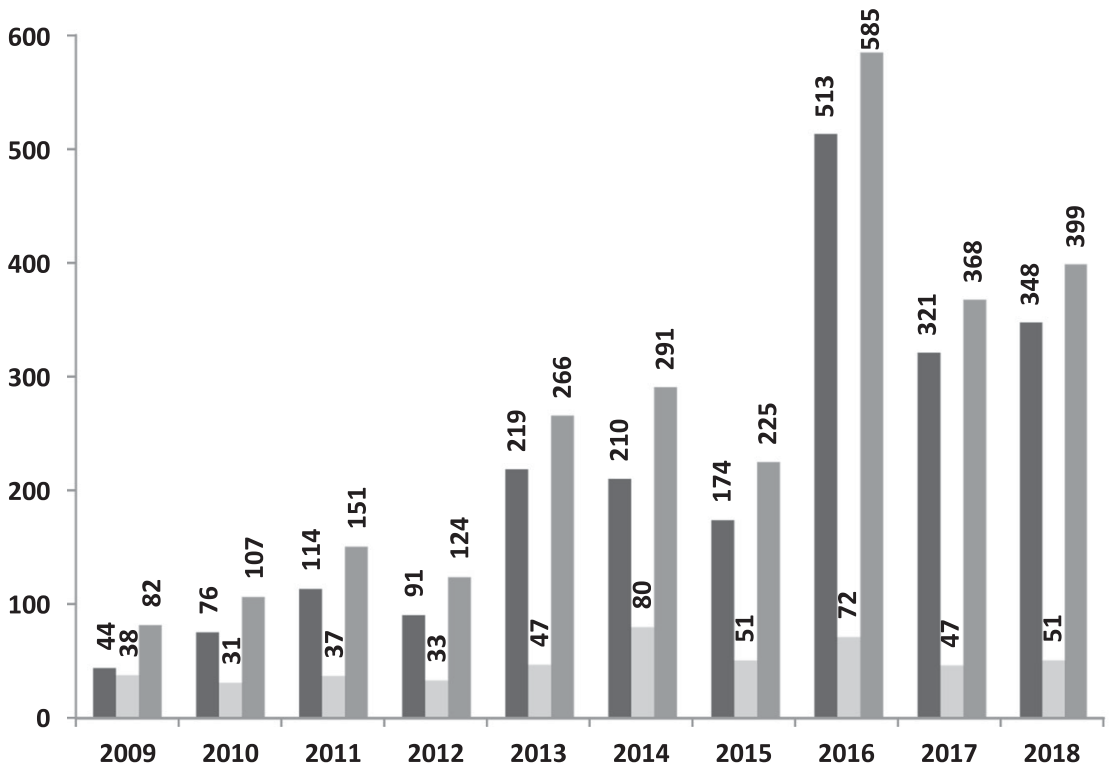

Figure 1. Annual Statistical Report on UN Procurement for Security Services and Equipment (2009-2018). Source: Prepared by authors using data from Annual Statistical Report on United Nations Procurement from 2009-2019, accessible at https://www.ungm.org/Public/ASR.

Notes: $Y$ axis shows the annual UN expenditures in millions of $\$$, rounded to the nearest million. $X$ axis indicates the relevant year. First column from the left represents UN expenditures for security services, second column represents UN expenditures for security equipment, third column shows total UN expenditures for security services and equipment in the given year.

academic literature, ${ }^{67}$ the aforementioned reports only offered two interlinked explanations for the proliferation of private security procurement in the past decade: (1) an ever-increasing demand for UN presence in increasingly complex (post)conflict areas; and (2) the absence of other means to ensure the protection of UN personnel, premises, and operations by the host country, other Member States, or the UN system in such environments. Growing concerns about the lack of security for UN staff and premises have also prompted the Secretary-General to conclude in May 2011 'that the Organization should resort to the use of armed private security companies and their personnel only as the last option to enable United Nations activities in high-risk environments ... when a United Nations security risk assessment had concluded that other alternatives... were insufficient'. ${ }^{68}$ This

\footnotetext{
${ }^{67}$ These include the availability, professionalism, and deployment readiness of PMSCs' personnel; better organization and equipment; and lower costs. For a detailed discussion, see Bures, "Private Military Companies"; Patterson, "A Corporate Alternative to United Nations Ad Hoc Military Deployments"; Spearin, "UN Peacekeeping and the International Private Military and Security Industry".

${ }^{68}$ UN Secretary-General 2012, para. 8.
} 


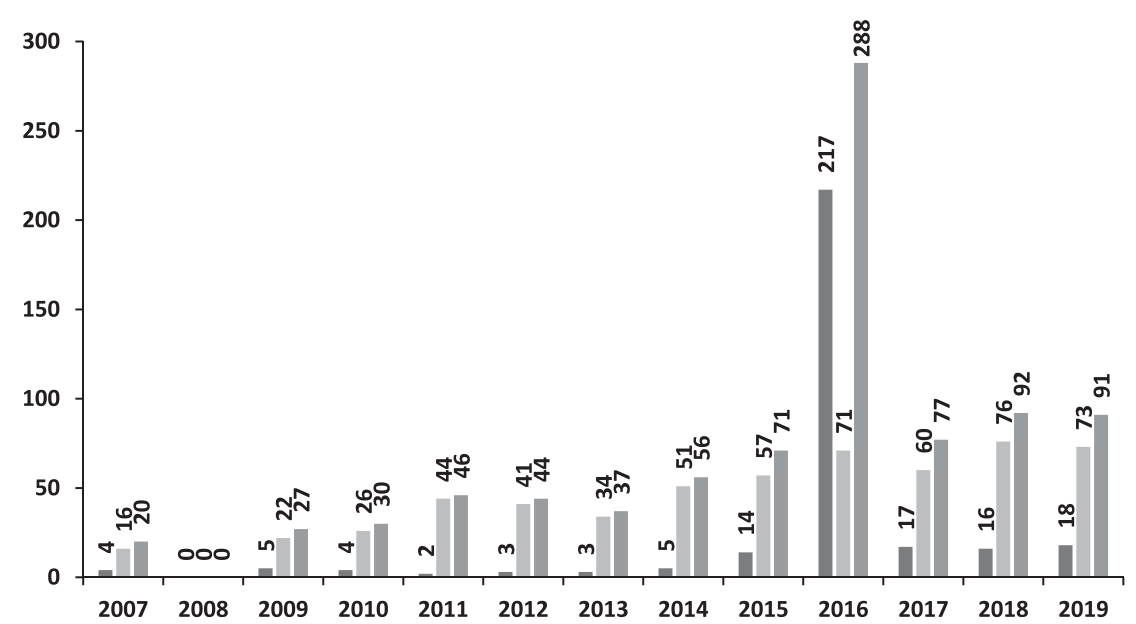

Figure 2. UN Headquarters and Local Missions' Procurement of Security Services and Equipment (2007-2019). Source: Prepared by authors using data from the UN Procurement Division website from 2007-2019, accessible at https://www.un.org/Depts/ptd/ procurement-by-commodity-table-detail/2019.

Notes: $Y$ axis shows the annual UN expenditures in millions of $\$$, rounded to the nearest million. $X$ axis indicates the relevant year. First column from the left represents UN Headquarters' expenditures for "security and safety services and equipment," second column represents UN local missions' expenditures for "security and safety services and equipment," third column shows the total UN Headquarters and local missions' expenditures for "security and safety services and equipment" in the given year. No data is available for 2008. For 2016-2019, all columns provide data for expenditures for a further unspecified category titled "security." In absence of any explanations provided by the UN, we speculate that the abrupt 2016 hike in UN Headquarters' expenditures is primarily due to changes in the terminology and/or methodology used to compile the relevant UN statistics.

represented the first official public acknowledgment of the need for PMSCs contracting in the UN system.

Beyond this explicit justification of UN use of PMSCs by the Secretary General, followed by the publication of the first official policy ${ }^{69}$ and specific guidelines on the use of PMSCs by the $\mathrm{UNDSS}^{70}{ }^{70}$ there are a remarkably small number of UN officials' ad hoc statements on this topic. Notably, former UN Secretary General Kofi Annan argued in 1998 that 'the world may not be ready to privatize peace'. ${ }^{71}$ Jean-Marie Guéhenno, former Under-Secretary General for Peacekeeping Operations, was also 'opposed to expansive new security privatization'. ${ }^{72}$ Few other parts of the UN system have officially stated their views on PMSCs. Two notable exceptions include the 2002 report of the Secretary General on UN outsourcing practices, which stated that

\footnotetext{
${ }^{69}$ UN Department of Safety and Security, "United Nations Security Policy Manual, Chapter IV," para. 3.

${ }^{70}$ UN Department of Safety and Security, "Guidelines on the Use of Armed Security Services from Private Security Companies."

${ }^{71}$ United Nations, "Secretary-General Reflects on 'intervention' in Thirty-Firth Annual Ditchley Foundation Lecture."

${ }^{72}$ Cited in Pingeot, "Dangerous Partnership," 23.
} 
contracting out security services 'may compromise the safety and security of delegations staff and visitors' and noted that the use of private guards will be phased out in due course' and replaced with UN staff members. ${ }^{73}$ For its part, the Office for the Coordination of Humanitarian Affairs raised its concerns about PMSCs' role in war-torn areas in its 2004 guidelines on humanitarianmilitary interactions in Iraq, noting that they were 'increasingly becoming a target' and raised 'problems of operational control, accountability, and liability' ${ }^{74}$ In her 2007 book, Percy cited only three interviews with UN officials to support her claim that 'the depth of international dislike for mercenaries would prevent the UN from ever using private force in a peacekeeping capacity, no matter how useful they might be'. ${ }^{75}$

For our analysis, however, the UN's tendency to remain silent on the use of private security providers has one crucial advantage - it allows us to mainly focus our content analysis on the reports of the UN Working Group, the only UN body specifically tasked with covering the activities both traditional mercenaries and PMSCs. ${ }^{76}$ This analysis reveals that while its initial reports (published from 2005-2008) largely echoed the self-determination, national-sovereignty and human-rights violations critiques from the annual reports published by the Working Group's predecessor (the Rapporteur), from 2008 onwards, the focus has gradually shifted to the regulation of PMSCs, but remained deeply critical. ${ }^{77}$ In order to more tightly regulate the activities of PMSCs, the Working Group repeatedly pointed out the need for a new international legally binding regulatory instrument replacing the mostly ineffective 1989 UN International Convention against the Recruitment, Use, Financing and Training of Mercenaries. In 2009, pending a request by the Human Rights Council, the Working Group presented such an instrument - the UN Draft International Convention on the Regulation, Oversight, and Monitoring of Private Military and Security Companies. ${ }^{78}$ Albeit this Draft Convention has had few practical implications thus far, it represents the first UN attempt to step into the definitional debate regarding PMSCs, since the 1989 UN Convention, as well as earlier legal instruments (especially Article 47 of the 1977 Protocol Additional to the Geneva Conventions), defined mercenaries only.

Our software analysis highlights some key aspects of UN Working Group talk on PMSCs. Even if the Working Group concedes that 'PMSCs are not

\footnotetext{
${ }^{73}$ UN General Assembly, "Outsourcing Practices - Report of the Secretary-General," para. 4.

${ }^{74} \mathrm{UN}$ Office for the Coordination of Humanitarian Affairs, "Guidelines for Humanitarian Organisations on Interacting with Military and Other Security Actors in Iraq," 5.

${ }^{75}$ Percy, Mercenaries, 224.

${ }^{76}$ UN Human Rights Office of the High Commissioner, "UN Working Group on the Use of Mercenaries."

${ }^{77}$ The Working Group reports are available at http://ap.ohchr.org/documents/dpage_e.aspx?m=152. The Special Rapporteur reports are available at http://ap.ohchr.org/documents/dpage_e.aspx?m=105

${ }^{78}$ For an analysis of the Draft Conventions provisions, as well as their shortcomings, see Østensen, "UN Use of Private Military and Security Companies."
} 
mercenaries' (A/HRC/15/25Add.6) and acknowledges that, according to most of the experts they consulted, 'the existence of a State monopoly on the use of force does not preclude States from delegating certain functions involving the use of force to private actors' (A/66/317), the portrayal of PMSCs and security privatization remains overwhelmingly negative. Up until its latest reports, the Working Group frames PMSCs as problematic actors by focusing on human rights violations by armed guards protecting extractive industry facilities, the use of child soldiers by PMSCs, and the abuses arising from the privatization of prisons and migrant detention centres.

The wording used to describe PMSCs' activities and their implications is fraught with derogatory terms. For example, a 2017 report still stresses that ' $t \mathrm{t}$ ] he ever-increasing privatization of security and military functions and the general growth of the private military and security industry across international boundaries raise serious questions about the legitimacy of the private use of force' and poses 'great risks for the violation of human rights' (A/HRC/36/47). This mindset is epitomized by the frequency of negative associations between PMSCs and unlawful behaviour. PMSCs and their employees are consistently flagged as potentially responsible for 'violations' of human rights, international humanitarian law, and domestic law (22 iterations), 'abuses' (38 iterations), as well as criminal behaviour and wrongdoings (14 iterations). Specifically, the Working Group repeatedly holds PMSCs responsible for instances of excessive or arbitrary use of force (5 iterations), which, in turn, has caused killings, casualties, and great injury (6 iterations), as well as 'physical violence, acts of threats and intimidation'. Private guards are held responsible for a wide range of crimes, including 'sex trafficking' and 'inappropriate sexual behaviour', 'repression of social protests', as well as 'abuse' and 'neglect of prisoners'. These wrongdoings are exacerbated by the persistence of a climate of 'impunity', a term iterated very frequently (29 times) with reference to private security contractors' behaviour. Companies at large are criticized for the illegal acquisition of weapons, poor vetting of employees and use of former child soldiers (an argument iterated 5 times), lobbying on governments to obtain contracts and lax legislation (8 times), or even engaging in 'corruption' (10 iterations) and 'bribery' ( 7 iterations), In one occasion, PMSCs are even stigmatized for the direct 'promotion of social and political instability' (A/HRC/42/36). Although the Working Group forcefully stresses the need for national and international regulation to mitigate the risks posed by PMSCs, several reports acknowledge that these risks cannot be entirely eliminated, because they are tied to the 'very nature of the private sector' $(\mathrm{A} / 72 / 150)$. The fact that PMSCs have 'profit as their main objective' causes 'perverse incentives' which 'undoubtedly risk economies being achieved through reductions in service'. These externalities are exacerbated by the fact that companies are solely 'responsible to their 
shareholders, not to the public', and 'private security guards do not defend common interests and the common good, but rather the private interests of those who hire and pay them' (A/HRC/7/7).

The combination of 'profit motive, efficiency concerns and a lack of accountability' are 'problematic realities ... that contribute to an increased risk of human rights violations and abuses'. (A/72/286) According to the Working Group, the trend towards commodification of security is, therefore, inherently undesirable. When privatized, security 'becomes a commodity that only the rich would be able to afford' (A/65/325) and 'will no longer be available as a public service to those who cannot afford to pay for it, thereby violating the right to equity' $(\mathrm{A} / \mathrm{HRC} / 7 / 7)$. Furthermore, the privatization of security poses challenges to the stability of the state system. The use of PMSCs undermines the state monopoly of violence as well as states' sovereignty (4 iterations) and does not only raise serious questions about 'the capacity of States to control their territory effectively' (A/HRC/36/47) but also allows them 'to dilute the responsibility of public authorities' (A/ 72/286).

In summary, even if the Working Group departed from the sweeping equation between PMSCs and mercenaries originally made by the Rapporteur it replaced, its discourses remain replete with a deep distrust towards private security forces and a strong normative preference towards the state monopoly of violence. This wariness is apparent in the frequency of associations between security privatization and adverse outcomes. Syntagmas referring to PMSCs and employees often contain adjectives like 'negative' (20 iterations) and nouns like 'harm' (19 iterations), 'impunity' (29 iterations), and most notably 'risk' (49 in-context iterations). The frequency of these negative references varies depending on the specific subjects and areas covered by each report, but it does not appear to have consistently decreased over time. Even if the Working Group generally refrained from labelling them as mercenaries, its portrayal of PMSCs continues to tap into the two main arguments underlying the anti-mercenary norm: their profit-oriented nature, which does not amount to a proper cause for engaging in the provision of coercion, and their unaccountable, unregulated nature, which undermines states' control over the use of force.

The findings of the content analysis are illustrated in Figure 3 below. As shown by the word cloud, the focus of the Working Group is mainly geared towards regulation, as epitomized by the frequency of words like 'resolution', 'order', 'act', 'decree', 'accountability', 'code', 'legislation', 'standards', and 'framework'. The iterations of words like 'violations', 'violence', 'criminal', 'abuses' and 'victims', however, reveals that the Working Group's discourse on PMSCs remained overwhelmingly bleak. This point is further illustrated by the frequent iterations of the word 'lack', often declined as 'lack of accountability' (29 iterations), 'transparency' (27 


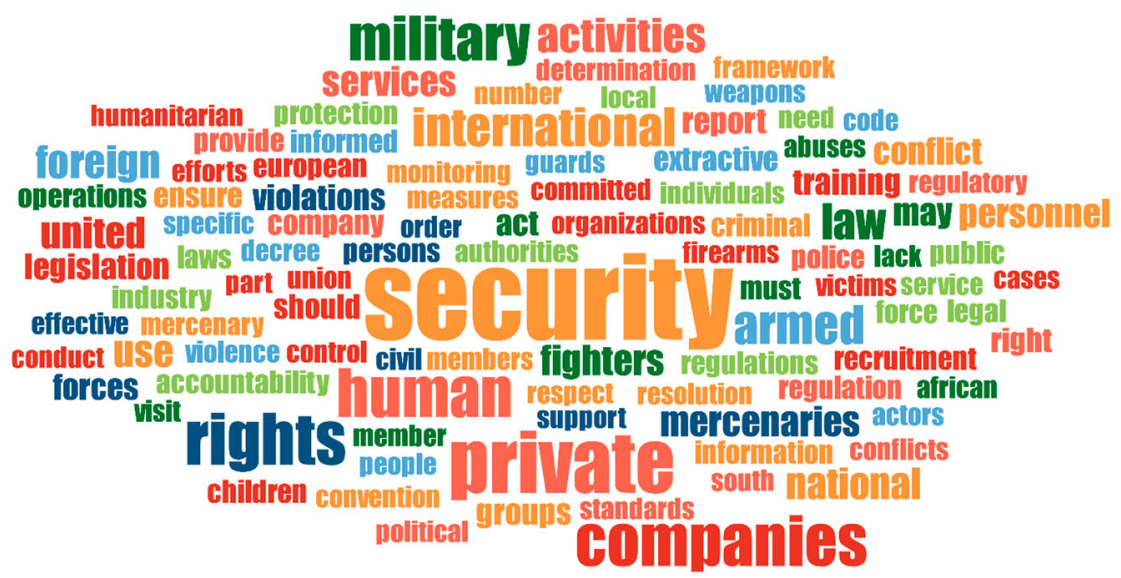

Figure 3. Word iterations within Working Group documents. Source: Prepared by authors using data from Working Group reports, 2008-2019.

Notes: Propositions, conjunctions, adverbs, pronouns, the auxiliary verbs be, have, and do, as well as overly frequent nouns "states", "nations, "governments", "working", and "group" were excluded from the analysis. A spreadsheet listing all words and their absolute and relative frequency, and a file of all from Working Group reports from 2008 to 2019, are included in the article's on-line supplementary materials.

iterations), 'regulation' (8 iterations), 'information' (5 iterations), and 'training (3 iterations). The same concepts are often expressed through similar nouns, like 'absence', or adjectives like 'insufficient', usually paired with terms like 'regulation', 'accountability', 'training', and 'performance'.

This talk is clearly at odds with the increasing use of PMSCs within the UN system. This tension is explicitly discussed in the 2014 report of the Working Group (A/69/338), which therefore warrants further examination. The report acknowledges the extensive use of PMSCs by the UN and the fact that this practice is deemed necessary to fill manpower gaps and mitigate the high risks faced by its personnel. However, the Working Group repeatedly stresses that outsourcing security in crisis management missions poses 'vast and complex challenges' to the UN, and may be both 'detrimental to the human rights of local populations and harmful to the credibility of the Organization'. While it acknowledges that 'the existing United Nations Guidelines on the Use of Armed Security Services from Private Security Companies can be improved' and provides several recommendations on how to do so, the document reiterates several principled objections against PMSCs, arguing that regulation 'cannot address all the challenges which outsourcing security to private contractors poses'. Consequently, the Working Group recommends that 'the provision of security functions should remain the primary responsibility of Member States, including providing security to the United Nations and its staff members'. To that end, the 
Working Group forcefully criticizes the vagueness and ambiguity of the last resort' criterion identified by the UN Guidelines, frequently stretched to cover situations where PMSCs are not necessarily the only solution available, but merely 'the most politically expedient option' (A/69/150).

As of 2020, these recommendations - as well as the broader, principled hostility to the privatization of both armed and unarmed security tasks displayed by the Working Group - continue to stand in stark contrast with the practice prevalent in all other parts of the UN system.

\section{Findings}

As amply documented in the existing literature, any organization with multiple principals and conflicting objectives is inevitably set to engage in organized hypocrisy. In the case of the UN, as Lipson noted, contracting out field operations to regional organizations like NATO or ECOWAS is a way of 'managing the pressure of inconsistent logics of consequences and appropriateness. ${ }^{79}$ However, the existing literature has not explicitly investigated the mismatch between UN contracting to PMSCs and the continuing rhetorical commitment to an orthodox understanding of the anti-mercenary norm, which parts of the organization actively promoted for much of its existence.

To fill this gap, we have made two interrelated claims. First, the creation of a Rapporteur (then transformed in the Working Group) on the use of mercenaries is a textbook example of the organization of hypocrisy. The Rapporteur was created in 1987 by the UN Commission on Human Rights to uphold the state monopoly of violence and voice the concern of former colonies that had suffered from mercenaries' activities in their territory. By then, however, the most powerful states in the international system had already shown minimal appetite for banning private providers of violence - as demonstrated by the refusal of all the UN Security Council permanent members to ratify the 1989 Convention against the Recruitment, Use, Financing and Training of Mercenaries. Even if all attempts to ban mercenaries had stalled and the private provision of security and military support had by then become mainstream, in 2005 the position of the Rapporteur was replaced by the Working Group, explicitly tasked with covering the activities of PMSCs since 2014. Arguably, the very existence and mandate of the Working Group - whose reports and recommendations had little to no influence on the operational practices of the other parts of the UN system - clearly illustrate Brunsson's notion of organization of hypocrisy. As the Working Group was de facto disconnected from the UN's internal working, its establishment and endurance seem to reflect an attempt to show compliance with some member states' normative expectations rather

${ }^{79}$ Lipson, "Peacekeeping," 22. 
than a genuine willingness to uphold a state monopoly of violence within the organization.

Second, we have argued that the gap between the UN's talk and action on PMSCS can be fruitfully conceptualized as a form of organized hypocrisy. Consistent with the concerns of former colonies in the Global South, the Rapporteur and Working Group have forcefully warned against security privatization and expressed a deep-seated wariness towards PMSCs. However, UN agencies and missions tasked with tackling crises worldwide have been plagued by a chronic shortage of manpower and support capabilities. The simultaneous expectation that the UN should both uphold a state monopoly of violence and operate in increasingly dangerous environments clashed with member states' unwillingness to endow the organization with sufficient resources. Therefore, all parts of the UN system were inevitably prompted to turn to the private sector, using the same PMSCs vocally stigmatized first by the Rapporteur and then by the Working Group. While the use of various PMSCs by different parts of the UN system increased steadily, their strong rhetorical condemnation of private security providers only became slightly more nuanced, but did not change significantly. The Rapporteur initially lumped mercenaries and PMSCs as two sides of the same coin, referring to PMSCs as 'the new operational model of mercenarism' that threatened the civilian populations, peace, and states' sovereignty. ${ }^{80}$ Even if it eventually distinguished between the two and toned down some of the Rapporteur's harshest critiques, the Working Group has continued to refer to PMSCs as problematic actors that are detrimental to self-determination and sovereign equality, consistently expressing principled objections to their use.

For at least two decades, the UN approach to PMSCs has been characterized by a persisting gap between rhetoric and behaviour concerning private providers of security and, therefore, by organized hypocrisy. The principled hostility to security privatization displayed by the Rapporteur and the Working Group is especially out of sync with the actual practice prevalent in all other parts of the UN system. While our analysis so far has concentrated on the talk by the Working Group, a significant albeit less glaring gap between talk and action can also be found when examining UN official policy on security outsourcing announced by the Secretary General in 2011 and formulated by the UNDSS in 2012. In both cases, the use of PMSCs is referred to as a last resort. The UNDSS Security Manual explicitly mentions that 'Armed security service from a private security company may not be contracted, except on an exceptional basis'. 81 This commitment to

\footnotetext{
${ }^{80}$ Ballesteros, "Report on the Question of the Use of Mercenaries as a Means of Violating Human Rights and Impeding the Exercise of the Rights of Peoples to Self-Determination," para. 68.

${ }^{81}$ United Nations Security Policy Manual, 93.
} 
restrict the use of PMSCs to exceptional circumstances is iterated 7 times between the Security Manual and the Guidelines on the Use of Private Security Services. As demonstrated by academic scholarship and denounced by the Working Group itself, however, UN agencies' outsourcing practices frequently depart from this last resort principle. UN bureaucratic inertia created a 'default PMSC option', leading many UN agencies to make an 'unnecessary choice despite legitimacy costs inherent in the limited command and control over PMSCs' ${ }^{82}$ Therefore, the talk, decisions, and action on private security formulated by different UN bodies and agencies are clearly decoupled.

\section{Conclusions}

By arguing that the UN approach to security privatization is fraught with hypocrisy, we do not intend to make a derogatory normative assessment against the Working Group or the UN at large. A degree of hypocrisy is inevitable for complex, political organizations with multiple masters, centres of agencies, and identities. In collective entities where those who talk, those who decide, and those who act are different actors, attaching moral connotations to organized hypocrisy makes no more sense than blaming as hypocritical someone 'afflicted with multiple personalities disorder. ${ }^{83}$ While organized hypocrisy deserves no moral condemnation, our findings do nevertheless have important implications for the debates on UN norm entrepreneurship, peacekeeping effectiveness, and reform.

First, the persisting mismatch between UN talk and action regarding PMSCs is in danger of challenging the UN's credibility as a norm entrepreneur. The failure to abide by the prohibition to use actors still widely seen as morally problematic and in conflict with an orthodox interpretation of the norm against mercenary use may cast doubts over the organization's genuine commitment to a variety of other norms, thereby hindering its ability to serve as a vehicle for norm socialization and diffusion. As noted by Bures and Meyer, the extensive resort to PMSCs appears at odds with the core norms that underlie the organization's very existence, like self-determination, anti-colonialism, and state sovereignty, thus threatening the UN's ontological security. ${ }^{84}$ Once unveiled, hypocrisy can severely tarnish the reputation of an organization. ${ }^{85}$ Should any significant scandals bring the use of PMSCs to the spotlight and raise media attention, the reputational

\footnotetext{
${ }^{82}$ Tkach and Phillips, "UN Organizational and Financial Incentives to Employ Private Military and Security Companies in Peacekeeping Operations," 115.

${ }^{83}$ Lipson and Weaver, "Varieties of Organized Hypocrisy," 16.

${ }^{84}$ Bures and Meyer, "The Anti-Mercenary Norm and United Nations' Use of Private Military and Security Companies."

${ }^{85}$ Cusumano, "Migrant Rescue as Organized Hypocrisy"; Lipson and Weaver, "Varieties of Organized Hypocrisy."
} 
damage attached to the UN failure to abide by the very norms it preaches may, therefore, fundamentally threaten the organization's authority and prestige.

Second, the many contradictions and ambiguities surrounding the UN use of PMSCs hinder the effectiveness of the outsourcing practices of its agencies. Vague, ill-identified criteria like the 'last resort' condition - formulated to pay lip service to the anti-mercenary norm but often disregarded in practice - only add complexity, confusion, and incoherence to the outsourcing process. Relatedly, the tension between the use of PMSCs in UN operations and the criticism of private security actors voiced by the Working Group have contributed to making most UN agencies 'remarkably shy' on their security contracting practices. ${ }^{86}$ As agreed on by all scholars who examined the UN's use of PMSCs, this lack of transparency hinders any objective assessment of contractor support to UN missions, preventing the development of more coherent and effective security privatization policies. ${ }^{87}$ Moreover, the lack of transparency is also likely to reduce the oversight of PMSCs supporting UN operations, thereby aggravating the accountability gap identified by the Working Group as one of the fundamental problems associated with outsourcing security. Incoherent and insufficiently transparent outsourcing policies are especially detrimental to peacekeeping missions, exacerbating lack of communication, command and control between blue helmets from different nationalities and the private contractors supporting them.

Third, the overlap between the Working Group's discourse that continues to stigmatize the use of PMSCs and the extensive use of such actors may further delay UN reform. As already noted by Lipson, organized hypocrisy is detrimental to the effort of reforming UN peacekeeping, weakening the perception that reforms are actually needed in the first place. ${ }^{88}$ The gap between talk and action on PMSCs is especially likely to delay, and ultimately inhibit peacekeeping reform. By acting as a surrogate for the manpower that member states are either unwilling or unable to provide, an opaque resort to PMSCs delays any serious discussion on how to endow the UN with the resources needed to conduct peacekeeping and crisis management tasks in increasingly volatile environments.

Given the implications of the gap between talk and action documented in this article, future research should continue to investigate the organized hypocrisy of the UN resort to PMSCs. Specifically, in parallel with examining

\footnotetext{
${ }^{86}$ Bures and Meyer, "The Anti-Mercenary Norm and United Nations' Use of Private Military and Security Companies," 91.

${ }^{87}$ Bures and Meyer, "The Anti-Mercenary Norm and United Nations' Use of Private Military and Security Companies"; Østensen, "UN Use of Private Military and Security Companies"; Østensen, "In the Business of Peace"; Tkach and Phillips, "UN Organizational and Financial Incentives to Employ Private Military and Security Companies in Peacekeeping Operations."

${ }^{88}$ Lipson, "Peacekeeping."
} 
the talk of different actors within the UN system, future scholarship should also conduct a more in-depth examination of the use of PMSCs in UN field operations, combining both quantitative overviews of total financial expenditures, number of contracts, and contracted personnel employed, as well as qualitative studies of the scope, drivers and implications of the use of contractor support to specific missions.

\section{Disclosure Statement}

No potential conflict of interest was reported by the author(s).

\section{Funding}

This work was supported by the Czech Science Foundation under grant number 2007805 S.

\section{Notes on Contributors}

Oldrich Bures is the founding director of the Center for Security Studies and Professor of International Political Relations at Metropolitan University Prague. He also lectures at the Department of Security Studies, Faculty of Social Sciences, Charles University in Prague. His research is focused on (counter-)terrorism and privatization of security. He is the author of several monographs, including Private Security Companies: Transforming Politics and Security in the Czech Republic (Palgrave Macmillan, 2015), and co-editor of several edited volumes, including Security Privatization: How Non-security-related Private Businesses Shape Security Governance (Springer 2018). For a full list of publications, see https://www.researchgate. net/profile/Oldrich_Bures.

Eugenio Cusumano is assistant professor of International Relations at the University of Leiden and Jean Monnet Fellow at the European University Institute. His research, focusing on non-state actors' role in international crisis management, has been published in journals including Security Dialogue, The Journal of Strategic Studies, and Cooperation and Conflict as well as books by Oxford and Stanford University Press, Routledge, and Palgrave Macmillan. He has collaborated with the NATO Centre of Excellence on Civil-Military Cooperation and the EU Centre of Excellence on Hybrid Threats, and obtained research grants from the European Commission, the Fulbright-Schuman programme, the European University Institute, and the Gerda Henkel Foundation.

\section{ORCID}

Oldrich Bures (D) http://orcid.org/0000-0003-0714-1036

Eugenio Cusumano (D) http://orcid.org/0000-0002-7349-6639 


\section{References}

Advisory Committee on Administrative and Budgetary Questions. "Reports on the Department of Safety and Security and on the Use of Private Security." UN General Assembly, December 7, 2012. http://www.un.org/en/ga/search/view_doc. asp?symbol=A/67/624.

Ballesteros, Enrique. "Report on the Question of the Use of Mercenaries as a Means of Violating Human Rights and Impeding the Exercise of the Rights of Peoples to Self-Determination." Geneva: Commission on Human Rights, 54th Session, January 27, 1998. https://documents-dds-ny.un.org/doc/UNDOC/GEN/G98/ 102/97/PDF/G9810297.pdf?OpenElement.

Brewis, Joanna, and Richard Godfrey. "Never Call Me a Mercenary”: Identity Work, Stigma Management and the Private Security Contractor." Organization 25, no. 3 (2017): 335-53.

Brunsson, Nils. The Organization of Hypocrisy: Talk, Decisions, and Actions in Organizations. New York, NY: Wiley, 1989.

Brunsson, Nils. The Consequences of Decision-Making. Oxford, UK: Oxford University Press, 2007.

Bures, Oldrich. "Private Military Companies: A Second-Best Peacekeeping Option?" International Peacekeeping 12, no. 4 (2005): 533-46.

Bures, Oldrich, and Jeremy Meyer. "The Anti-Mercenary Norm and United Nations' Use of Private Military and Security Companies." Global Governance: A Review of Multilateralism and International Organizations 25, no. 1 (2019): 77-99.

Casiraghi, Matteo C. M. "Weak, Politicized, Absent: The Anti-Mercenary Norm in Italy and the United Kingdom, 1805-2017." Journal of Global Security Studies, e-first (2020). doi:10.1093/jogss/ogz076.

Cusumano, Eugenio. "Migrant Rescue as Organized Hypocrisy: EU Maritime Missions Offshore Libya between Humanitarianism and Border Control." Cooperation and Conflict 54, no. 1 (2018): 3-24.

DiMaggio, Paul J., and Walter W. Powell. "The Iron Cage Revisited: Institutional Isomorphism and Collective Rationality in Organizational Fields." American Sociological Review 48, no. 2 (1983): 147-60.

Egnell, Robert. "The Organised Hypocrisy of International State-Building." Conflict, Security \& Development 10, no. 4 (2010): 465-91.

Everett, Andrea L. Humanitarian Hypocrisy: Civilian Protection and the Design of Peace Operations. Ithaca: London: Cornell University Press, 2018.

Fitzsimmons, Scott. "A Rational-Constructivist Explanation for the Evolution and Decline of the Norm against Mercenarism." Journal of Military and Strategic Studies 11, no. 4 (2009). https://jmss.org/article/view/57615.

Hirschmann, Gisela. "Peacebuilding in UN Peacekeeping Exit Strategies: Organized Hypocrisy and Institutional Reform.” International Peacekeeping 19, no. 2 (2012): 170-85.

Holsti, Ole R. Content Analysis for the Social Sciences and Humanities. Reading, MA: Addison-Wesley Pub. Co., 1969.

Howe, Herbert M. "Private Security Forces and African Stability: The Case of Executive Outcomes." The Journal of Modern African Studies 36, no. 2 (1998): 307-31.

International Committee of the Red Cross. "The Montreux Document on Private Military and Security Companies.” May 2, 2011. https://www.icrc.org/en/ publication/0996-montreux-document-private-military-and-security-companies.

Knill, Christoph, Yves Steinebach, and Xavier Fernández-i-Marín. "Hypocrisy as a Crisis Response? Assessing Changes in Talk, Decisions, and Actions of the 
European Commission in EU Environmental Policy." Public Administration 98, no. 2 (2020): 363-77.

Krahmann, Elke. "The United States, PMSCs and the State Monopoly on Violence: Leading the Way towards Norm Change." Security Dialogue 44, no. 1 (2013): 53-71.

Krasner, Stephen D. Sovereignty: Organized Hypocrisy. Princeton, NJ: Princeton University Press, 1999.

Lavenex, Sandra. "Mutual Recognition and the Monopoly of Force: Limits of the Single Market Analogy." Journal of European Public Policy 14, no. 5 (2007): 762-79.

Lipson, Michael. "Peacekeeping: Organized Hypocrisy?" European Journal of International Relations 13, no. 1 (2007): 5-34.

Lipson, Michael, and Catherine Weaver. "Varieties of Organized Hypocrisy." San Francisco, CA, 2008.

Liu, Hin-Yan, and Christopher Kinsey. "Challenging the Strength of the Antimercenary Norm." Journal of Global Security Studies 3, no. 1 (2018): 93-110.

March, James G, and Johan P Olsen. Rediscovering Institutions: The Organizational Basis of Politics. New York: Free Press, 1989.

Meyer, John W., and Brian Rowan. "Institutionalized Organizations: Formal Structure as Myth and Ceremony." American Journal of Sociology 83, no. 2 (1977): 340-63.

Østensen, Åse Gilje. "UN Use of Private Military and Security Companies: Practices and Policies." Geneva: DCAF, 2011. http://www.dcaf.ch/Publications/UN-Use-ofPrivate-Military-and-Security-Companies-Practices-and-Policies.

Østensen, Åse Gilje. "In the Business of Peace: The Political Influence of Private Military and Security Companies on UN Peacekeeping." International Peacekeeping 20, no. 1 (2013): 33-47.

Panke, Diana, and Ulrich Petersohn. "Why International Norms Disappear Sometimes." European Journal of International Relations 18, no. 4 (2012): 719-42.

Panke, Diana, and Ulrich Petersohn. "Norm Challenges and Norm Death: The Inexplicable?" Cooperation and Conflict 51, no. 1 (2016): 3-19.

Patterson, Malcolm. "A Corporate Alternative to United Nations Ad Hoc Military Deployments." Journal of Conflict and Security Law 13, no. 2 (2008): 215-32.

Percy, Sarah. Mercenaries: The History of a Norm in International Relations. Oxford: Oxford University Press, 2007.

Percy, Sarah. "The Unimplemented Norm." In Implementation and World Politics, ed. Alexander Betts, and Phil Orchard, 68-84. Oxford: Oxford University Press, 2014.

Petersohn, Ulrich. "Reframing the Anti-Mercenary Norm: Private Military and Security Companies and Mercenarism.” International Journal: Canada's Journal of Global Policy Analysis 69, no. 4 (2014): 475-93.

Pingeot, Lou. "Dangerous Partnership - Private Military \& Security Companies and the UN.” Berlin: Rosa Luxemburg Foundation, July 2012. http://www.rosalux.de/ publication/38598/dangerous-partnership.html.

Spearin, Christopher. "UN Peacekeeping and the International Private Military and Security Industry.” International Peacekeeping 18, no. 2 (2011): 196-209.

Thomson, Janice E. Mercenaries, Pirates, and Sovereigns: State Building and Extraterritorial Violence in Early Modern Europe. Princeton, NJ: Princeton University Press, 1994.

Tkach, Benjamin, and Joe Phillips. "UN Organizational and Financial Incentives to Employ Private Military and Security Companies in Peacekeeping Operations." International Peacekeeping 27, no. 1 (2020): 102-23. 
UN Department of Safety and Security. "Guidelines on the Use of Armed Security Services from Private Security Companies.” OHCHR, November 8, 2012. http:// www.ohchr.org/Documents/Issues/Mercenaries/WG/StudyPMSC/

GuidelinesOnUseOfArmedSecurityServices.pdf.

UN Department of Safety and Security. "United Nations Security Policy Manual, Chapter IV.” OHCHR, November 8, 2012. http://www.ohchr.org/Documents/ Issues/Mercenaries/WG/StudyPMSC/UNSecurityPolicyManual.pdf.

UN General Assembly. Definition of Aggression, 19/3314 \$ (1974). https:// documents-dds-ny.un.org/doc/RESOLUTION/GEN/NR0/739/16/IMG/ NR073916.pdf?OpenElement.

UN General Assembly. Definition of Aggression, 19/3314 \$ (1974). Implementation of the Declaration on the Granting of Independence to Colonial Countries and Peoples, $2465 \S$ (1968). https://documents-dds-ny.un.org/doc/RESOLUTION/ GEN/NR0/244/25/IMG/NR024425.pdf?OpenElement.

UN General Assembly. Definition of Aggression, 19/3314 \$ (1974). Importance of the universal realization of the right of peoples to self-determination and of the speedy granting of independence to colonial countries and peoples for the effective guarantee and observance of human rights, 31/34 $\$$ (1976). https:// documents-dds-ny.un.org/doc/RESOLUTION/GEN/NR0/302/17/IMG/ NR030217.pdf?OpenElement.

UN General Assembly. Definition of Aggression, 19/3314 \$ (1974). "Outsourcing Practices - Report of the Secretary-General,” July 2, 2002. http://www.un.org/ga/ search/view_doc.asp?symbol=A/57/185.

UN Human Rights Office of the High Commissioner. "UN Working Group on the Use of Mercenaries," 2016. http://ink.brightcove.com/services/player/ bcpid1722935254001/?autoStart=false $\&$ bctid $=4370733021001 \&$ height $=$ 270\&secureConnections $=$ true $\&$ width $=480$.

United Nations. "Secretary-General Reflects on 'intervention' in Thirty-Firth Annual Ditchley Foundation Lecture.” Press Release. New York, June 26, 1998. https:// www.un.org/press/en/1998/19980626.sgsm6613.html.

UN Office for the Coordination of Humanitarian Affairs. "Guidelines for Humanitarian Organisations on Interacting With Military and Other Security Actors in Iraq." Refworld, October 20, 2004. http://www.refworld.org/docid/ 4289f2f74.html.

UN Secretary General. "Use of Private Security.” UN General Assembly, October 22, 2012. https://documents-dds-ny.un.org/doc/UNDOC/GEN/N12/561/96/PDF/ N1256196.pdf?OpenElement.

UN Security Council. UN Security Council Resolution 241 (1967) (1967). http:// www.un.org/en/ga/search/view_doc.asp?symbol=S/RES/241(1967).

UN Security Council. UN Security Council Resolution 241 UN Security Council Resolution 405 (1977). http://www.un.org/en/ga/search/view_doc.asp?symbol=S/ RES/405(1977).

UN Working Group on the Use of Mercenaries. "Use of Mercenaries as a Means of Violating Human Rights and Impeding the Exercise of the Right of Peoples to SelfDetermination." UN General Assembly, August 21, 2014. http://www.un.org/en/ ga/search/view_doc.asp?symbol=A/69/338.

Weaver, Catherine. Hypocrisy Trap: The World Bank and the Poverty of Reform. Princeton, NJ: Princeton University Press, 2008.

White, Adam. "Mercenarism, Norms and Market Exchange: Reassembling the Private Military Labour Market.” International Sociology 33, no. 4 (2018): 523-40. 